Ritva Jakku-

Sihvonen

\title{
RITVA JAKKU-SIHVONEN
}

\section{Tuloksellisuuden käsite koulutuksen suunnittelun ja kehittämisen näkökulmasta}

Opetustoimessa niin kuin muuallakin yhteiskunnassa keskustellaan aktiivisesti toiminnan tuloksellisuudesta. Kiristynyt taloudellinen tilanne on entisestään lisännyt niiden toimien määrää, joiden tarkoituksena on arvioida opetustoiminnan tehokkuutta.

Keskustelu tuloksellisuudesta ei tietenkään ole uusi ilmiö. Tuloksellisuus on aina ollut opetustoimessa tärkeä. Tuskin kukaan opettaja, opiskelija tai alan hallintoviranhoitaja on koskaan toimillaan tähdännyt tuloksettomuuteen!

Keskustelua opetustoimen tuloksellisuudesta on kuitenkin viime aikoina leimannut tuloksellisuuden yhdistäminen aktiiviseen keskusteluun tulosjohtamisesta. Väliin keskustelusta on kadonnut toiminnan sisällön keskeisyys. Näin tulosjohtamiseen kytkyssä ollut tuloksellisuus-keskustelu on juuttunut turhautuneeksi tulosmittareiden ar- vosteluksi. Joskus on näyttänyt jopa siltä, että johtamisprosessin toteuttamisen muoto nousee keskustelun perusongelmaksi opetuksen kehittämisedellytyksien jäädessä sivuun.

\section{Tuloksellisuuden arvioinnin käsitteet}

Toiminnan tuloksellisuuden arvioinnissa käytetyt käsitteet vaihtelevat eri tutkijoiden, eri alojen edustajien ja eri hallinnonalojen kesken. Laajasti on keskusteltu mm. käsitteen koulutuksen vaikuttavuus sisällöstä erityisesti koulutuksen suunnittelua palvelevassa tuloksellisuustutkimuksessa.

Suomalaisessa julkishallinnossa on korostettu sitä, että toiminta on tuloksellista silloin, kun aikaansaatujen palvelujen taso on käytettävissä oleviin resursseihin nähden hyvää. 
Valtionhallinnon kehittämiskeskuksen julkaisemassa esitteessä "'Tulosohjaus tulee virastoihin" (1990) todetaan tuloksellisuudesta seuraavaa: "Mikäli toiminta on yhtäaikaisesti sekä tuottavaa, taloudellista että vaikuttavaa, sen sanotaan olevan tuloksellista". Tämän määritelmän pohjalta korvaamalla käsite tuottavuus tehokkuudella on mielestäni mahdollista ainakin opetustoimen alueella pyrkiä etsimään tuloksellisuudelle sellaista sisällöllistä määrittelyä, joka edistäisi käytännön kehittämistyötä. Käsitteen tuottavuus korvaaminen tehokkuudella perustuu siihen, että opetustoimen alueella tuottavuus on monin tavoin sidoksissa koulutusjärjestelyjen tehokkuuteen.

\section{Mitä tuloksellisuus opetustoimessa on?}

Tuloksellisen toiminnan kannalta on tärkeätä, että opetustoiminta on siten järjestetty, että oppiminen on toiminnan keskiössä, opetustoimintaa tuottava koulutusjärjestelmä on toimintakykyinen ja käytettävissä olevat taloudelliset resurssit tulevat mahdollisimman tehokkaasti käytetyiksi hyväksi.

Tuloksellisuutta indikoivat toiminnan vaikuttavuus, taloudellisuus ja tehokkuus. Tuloksellisuus on siis yläkäsite, jonka ulottuvuuksina (alakäsitteinä) käytetään vaikuttavuutta, tehokkuutta ja taloudellisuutta. Tältä perustalta voidaan esittää seuraava määritelmä opetustoiminnan tuloksellisuudelle:

Tuloksellista koulutus on silloin, kun kansallisella ja kansainvälisellä tasolla koulutusjärjestelmän kullekin organisaatiomuodolle, oppilaitokselle ja yksilön oppimistoiminnalle asetetut tavoitteet on saavutettu hyvin.

\section{Oppimisen laadukkuus - vaikuttavuuden ydinkysymys}

Vaikuttavuutta voidaan ja tulee kasvatustoiminnassa tarkastella yksilötasolla ja yhteistasolla. Vaikuttava koulutus edistää yksilön kasvua ja tuottaa elämää palvelevia, kansainvälisissä vertailuissakin riittävän korkeatasoisia tuloksia, jotka vastaavat yhteiskunnan koulutukselle asettamia tavoitteita.

Yksilötasolla vaikuttavuus ilmenee suotuisana persoonallisuuden kehityksenä ja myönteisinä op- pisaavutuksina. Vaikuttavuuden arvioinnin kriteerit siis määräytyvät yksilön kohdalla sekä kasvatuksellisista lähtökohdista että oppimisen onnistumisesta.

Yhteistasolla vaikuttavuus on opetustoimen kehittämisen kannalta määriteltävissä pätevien ja toimintakykyisten opiskelija- ja työntekijävoimien tuottamiseksi. Tällöin opetusta arvioidaan suhteessa elämän koko kirjoon. Keskeisimmän käytännön arviointikriteerit perustuvat siihen, miten hyvin opittu palvelee työelämää ja kulttuurin kehittymisen tarpeita. Oppisisältöjä arvioidaan sekä niiden tieteellisen pätevyyden että yhteiskunnallisen relevanttiuden osalta.

Se koulutus on vaikuttavaa, mikä kykenee tuottamaan kulloisissakin olosuhteissa ihmisen tarvitsemia tieto-taito -tuloksia.

\section{Koulutusjärjestelmä - tehokkuuden arvioinnin keskiössä}

Lähtökohtana koulutusjärjestelmän tehokkuuden arvioinnissa on se, että opetustoiminta on tehokasta silloin, kun se on järjestetty oppijan ja yhteiskunnan kannalta rakenteiden ja ajan osalta optimaalisimmalla mahdollisella tavalla.

Tehokkuuden arvioinnissa keskeisiä seikkoja ovat koulutusjärjestelmän rakenteen joustavuus, toimivuus ja aika. Joustavuus on koulutusjärjestelmän ja opetusjärjestelyjen kyky palvella yksilöä ja ympäristöä siten, että oikeata koulutusta on oikeaan aikaan ja oikeassa paikassa tarjolla oikeille ihmisille. Toimivuus kytkeytyy samaan asiaan siten, että järjestelmässä ei ole päällekkäisyyksiä, vaan on oikeanlaista oppilaitoksien ja opetustyhmien välistä yhteistyötä. Yksilön kannalta toimivuus merkitsee mahdollisuutta yksilöllisiin opintoväyliin.

Aika on tehokkuuden arvioinnissa tärkeätä. Aikaa tulee tarkastella sekä opetuksen että opiskelun keston näkökulmasta. Arvioinnissa tulisi selvittää opiskeluaikojen yksilöllistä sääntelymahdollisuutta siten, että tarkataan päällekkäissuorituksia ja sitä, että suorituksien jaksottamismahdollisuuksia on tarjolla.

Tehokkuutta selvitettäessä kysytään siis sitä, onko opetustoiminta valtakunnallisella, alueellisella ja oppilaitos- sekä yksilötasolla rakenteeltaan 
joustavaa ja toimivaa ja onko se oikea-aikaista ajankohdan ja keston osalta?

\section{Taloudellisuus - tuloksellisen toiminnan yksi ulottuvuus}

Toiminnan taloudellisuus on ehkä eniten keskusteltu tuloksellisen toiminnan ulottuvuus. Tuloksellisuuteenhan kuuluu se, että käytettävissä olevat taloudelliset resurssit käytetään mahdollisimman järkevästi. Taloudellisuutta arvioitaessa on otettava huomioon kaikki koulutuksesta aiheutuneet kustannukset. Taloudellisuutta arvioitaessa mukana ovat yhteiskunnan ja yksilön taloudelliset koulutusinvestoinnit: raha, työkustannukset, kiinteistöinvestoinnit, oppilaitoksen laite- ja oppimateriaalikustannukset, matkakustannukset ja ne investoinnit, jotka yksilölle ovat välttämättömiä, jotta opiskelu on mahdollista (esimerkiksi etäopiskelun edellyttämät laiteinvestoinnit). Tämä on erityisen keskeistä nyt, kun julkisten menojen supistaminen on tähtäimessä. Tarpeellista on seurata, mitä koulutus todella maksaa ja kenen maksettavaksi kustannukset osoitetaan.

\section{Tuloksellisuuden arvioinnin menetelmät käsitteisiin sidoksissa}

Opetustoimessa arviointia suoritetaan sekä määrällisenä että laadullisena. Tuloksellisuuden kaikki ulottuvuudet: vaikuttavuus, taloudellisuus ja tehokkuus tulee ottaa puntarointiin arviointitietoa kerättäessä. Kutakin ulottuvuutta varten on eri opetustoimen osa-alueilla tarpeellista luoda yhteiseen sopimukseen perustuvia, käsitteellisesti hyvin perusteltuja arviointimenettelyjä sekä tilasto- ja kustannustunnuksia. Tärkeätä on että sekä yksilö- että yhteisötaso ovat kaikissa arvioinneissa mukana. Menetelmällinen kehittäminen edellyttää myös valtakunnallisen, alueellisen ja oppilaitoksen tason yhtä hyvin kuin opettaja-oppilastason aktiivisuutta, jotta toiminnan käytäntöä ohjaavat ja rajoittavat erityispiirteet voidaan ottaa huomioon.

Opetushallinnossa vaikuttavuuden arvioinnin kehittäminen on erityisen tärkeätä. Opetus-, oppimis- ja kasvatustoiminnan vaikuttavuuden arvioinnin yhteydessä tulee kiinnittää erityistä huomiota siihen, että arviointitieto kerätään siinä muodossa, että sitä voidaan käyttää hyväksi tuloksellisuuden arvioinnissa tehokkuus- ja taloudellisuustietojen rinnalla. Näin luodaan realistiset edellytykset tulokselliseen koulutuksen suunnitteluun ja opetustoimen laadukkaaseen kehittämistyöhön. 